\title{
The concept of light and color as a key element of experiencing 'feeling architecture'
}

\author{
Agnieszka Chęć-Małyszek \\ Department of Architecture, Urban and Spatial Planning, Faculty of Civil Engineering and \\ Architecture, Lublin University of Technology, e-mail: a.chec-malyszek@pollub.pl, ORCID: \\ 0000-0001-6004-0635
}

\begin{abstract}
This article investigates the role of light in the perception of contemporary architecture. Light is an essential element that creates and reveals the beauty of architecture, emphasizes its aesthetic values, and allows us to feel the unlimited space „with one's whole self'. Since time immemorial, light in combination with colour has played an important role at the design stage and later in its reception. Nowadays, technological and civilization progress has contributed to the increase in the role of light and color, enabling their application already at the moment of design. Increasing expectations towards architects have led to an intensification of the phenomenon, which is increasingly expressed in projects filled with light and colour.
\end{abstract}

Keywords: architecture, light in architecture, feeling of architecture

\section{Introduction}

Since the beginning of the centuries, light has inspired people as a gift of nature, sustaining life on Earth. It constitutes an active element of life, being in the past as well as now, a source of energy. It is one of the key elements of expression, without which it would be impossible to perceive the architectural space and the elements that it is composed of.

Light is considered to be one of the most important factors defining architecture - it is a ,play of solids in light”, as Le Corbusier [1] wrote. Since the earliest times, it has been used in the creation of plastic shapes of buildings and interiors. In ancient times, buildings which worshipped light as the main source of life were erected. Nowadays, it inspires architects, becoming a material and an independent element of composition, serving to express ideas, philosophy and current trends of the century.

Currently, thanks to the widely developed technology in construction, light allows to create both architectural and urban spaces. Thanks to its versatility and proximity to the human perception senses, it gives a unique character to the objects. It is more than just making the building more visible, it is a creation of the environment, atmosphere, monumentality, intimacy and tranquility, which strongly influence the feelings and emotions of a person. It builds a three-dimensional space, emphasizing the atmosphere and aesthetic values of the building.

Today, the concepts of „light” and „colour” have been characterized as physical or psychological-physical phenomena in which colour is considered to be a kind of light radiation. Le Corbusier, in his work "Polychromie architecturale", defining the interdependencies between light and colour, called ,colour, daughter of light”, so for modernists colour had the 
Postmodern concepts in architecture reduced its essence to the idea of space in which they became a source and field of activity [3]. Architecture is created, recognized, understood, „felt”, and remembered primarily as compositions of three-dimensional forms placed in light and colour. Architectural perception is achieved by synthesizing the interdependencies among the individual elements of buildings that co-create them, constituting an excellent source of colour emission. The concepts of light and colour have undergone various transformations over the years, but their strength and power of meaning have not diminished to this day, playing a key role in the process of feeling architecture.

The aim of this work is to show the meaning of light and colour in the perception, or in other words, the ,feeling” of contemporary architecture. The importance of these two elements was presented on the example of residential and public buildings.

\section{Light in architecture}

The phenomenon of architecture consists in engaging all the most important senses of humans: sight, touch, hearing, and sense of smell at the moment of its reception, which allows to „feel” the beauty with the whole of oneself. The basic elements that make up the visual image of architecture are light and colour, without which it loses its monolithic character and ceases to exist.

The notion of „light” was shaped as a result of long-term research, during which it was characterized as a physicochemical or physiological-psychological phenomenon. It is considered to be an electromagnetic wave that propagates at a huge speed in various transparent material media [4]. The phenomenon of light made it possible to decipher not only its physical nature, but above all its internal structure of matter and the role it plays in the process of „feeling” - the perception of architecture. Colloquially, light is the visible part of the electromagnetic radiation received by the retina of the human eye, which includes visible, ultraviolet, and infrared rays of light.

For many centuries scientists have been asking themselves the same question: what is light? Greeks are considered to be precursors of the phenomenon of light reflection and the discovery of a straight line of light rays. They claimed that light from heavenly bodies has a different character than other types of radiation. According to Greek theory, the source of light is therefore the human eye, which sends out an invisible kind of sensors - i.e. light, and informs people about the shape, size and location of objects [5].

Already in the 6th century B.C., Pythagoras was the first to notice that light comes from the sun and stars and that it is emitted by every luminescent celestial body. By splashing on the objects encountered, it bounces off them, accidentally hitting the eye and causing them to be seen. The turn of the 5th/4th century B.C. saw Plato's theory that light is three separate streams of light from the eyes, the object visible, and the light source that interact with each other $[6,7]$.

Euclid was the next one to study geometric optics, and it was he who formulated the principle of the rectilinear propagation of light and the law of reflection. He noticed that light falls straight and reflects. Newton, however, claimed that the propagation of light is based on the straight motion of tiny molecules passing from a given source to the human eye, producing an impression of light. This theory was called the „,corpuscular theory of light”. Further research in the 19th century by Young and Fresnel led to the discovery of diffraction and light interference, confirming its wavy nature [8].

The above theories are the basic source of knowledge concerning the laws governing the 
same meaning as the material from which architecture was built at that time [2].

propagation and reflection of light. Their discovery is an important basis used in the design process, because thanks to the knowledge of these rules, architecture becomes predictable and shows the intention of the creator.

\section{Colour in architecture}

Man's vision of colours is due to the sense of sight, which is an essential tool in the perception of the outside world. It provides important information about its colours, shapes and phenomena occurring in it. The process of receiving elements of the external environment consists of complex psychological, physiological and physical processes. A person receives about $80 \%$ of the information visually from the environment, while the hearing organ has a complementary function and its share in obtaining information is relatively small. The process of seeing light and colour by humans plays a key role in the perception and feeling of architecture, positively influencing their well-being [9]. Colour contrast plays an important role in the process of colour vision, which contributes to colour change as a result of other stimuli acting simultaneously on the retina of the eye [10]. Therefore, light is one of the most important factors co-creating architecture, because without it, the form, texture and colour do not exist.

Colour in architecture for many years has been considered to be an insignificant factor, mainly used by interior designers. It was not until the 90 's of the 20th century that its interest and wide application in architecture came back. Today, the use of colour and light in the design process is connected with changing global trends. Colour is used to emphasize and give a specific character to a given space, according to the intentions of the architect and investors. The designers have at their disposal a wide range of different coloured building materials, which correspond to the current trends. The rapid development of technology and the emergence of new multicoloured materials used in construction, caused that the imagination of architects has no limits, which is visible in the newly designed buildings.

Designers and architects use their knowledge of colours when designing public and residential buildings. In addition to psychological effects, colour also has a therapeutic function, which is also often used at the design stage. Its skillful application allows the designers to warm up, cool down, lift or lower the room, and properly let in daylight, which enables the recipient to have a better insight into the depths of a given architecture.

By observing buildings from a certain distance, they may seem flat, because the human sense of perception is not able to separate the solids from the surroundings. The visible outline does not allow to distinguish its architectural depth and convex forms are perceived as undefined space. Colour in architecture, unlike in painting, plays a complementary role. It serves mainly to emphasize and highlight certain details, giving the building a unique character.

Primitive people used natural-coloured materials, which were an integral part of the landscape of the time, to build their homes. Later, when man discovered the way colours could be produced, it was possible to obtain a variety of, but still limited number of colours. When the colour of building materials began to depend on man, it began to be used on an increasing scale. For most people, colour has only symbolic meanings, and so in Sweden, for example, houses are often painted in deep red, imitating more permanent, old manor houses that used to be built of red brick.

Colour in architecture is used to emphasize the character of the building, accentuate 
its form, and show the most interesting elements or hide imperfections. It is not the most important element in the design process, as is the case in painting. Without colour, a work of art ceases to exist, while architecture gives an individual character by breaking up the monotony of a solid and giving it a new function.

Sometimes colours add lightness, or optically enlarge or reduce the space. The facility, designed for children and fun games, will have a multitude of colors, while the monumental and heavy architecture will be filled with subdued and soft colors. Colour in interiors serves the function of accentuating the form and architectural divisions. After choosing the right colour, it is possible to optically enlarge or reduce the size of the room, as well as shorten or extend it. Colour is a powerful means of expression for the architects, because thanks to it, they can not only emphasize the structure of the building, but also allow to create a unique architectural composition. It is therefore obvious that there is an unexplainable relationship among material, light, and colour.

It can be said that color is only a subjective feeling of every person, because when there is no light, also color disappears. Colour has a special impact on the psyche of a person, and colour in an individualized form influences emotional states.

Le Corbusier wrote: ,architecture is a wise, thoughtful play of solids in the light”, so the art is to create a building with appropriately selected colours, which will have a positive impact on the viewer. When Corbusier designed the houses in Pessac, he created the impression of a colourful composition floating in the air through the appropriate use of colour on the buildings. The introduction of lightweight reinforced concrete construction and the addition of colour, reduced the weight and monotony of the residential buildings of the time. In this way he created ,artistic sketches in colour”, a collage of overlapping, semi-transparent buildings intermingling in an unbelievable way.

Not long ago, colour was treated as not important and was only an addition to the architecture, little attention being paid to it. Over the years, its power has been appreciated and it has been used on an increasing scale to decorate buildings. In many towns and cities, the prefabricated housing estates were repainted using a rich palette of colours, which not only pleases the eye, but also helps to build the identity of the local community.

The designer of a residential estate at Smyczkowa Street in Lublin has created a high residential development with an internal street and courtyard. The density is high, so people often look into each other's windows and their balconies almost touch each other to make contacts. The architecture of residential buildings is a simple box shape, but what gives them the hallmarks of uniqueness, is a well-thought-out colour concept. In this housing estate, the focus was put on painting wall planes in some kind of patterns, interwoven with subdued colors. Some of them are dominated by shades of green, interspersed with yellow and red, while others have warm colors of oranges and greens. Graduation of colour intensity occurs when colours are exposed to the sun or the shade, and where twilight prevails, the colours get stronger. (Fig. 1 and 2) The presented residential complex is an example of an interesting social development, which improves living conditions not only through its shape or infrastructure, but in particular, creates a friendly atmosphere through the use of appropriately subdued colors.

The colour tradition is not a static phenomenon. Let us take Turin as an example, where for many years the yellow colour has been perceived as characteristic for this city, and in the 1960s more than 1,000 facades were repainted to this colour [10].

Therefore, colour on the one hand creates buildings, space and architecture as an 
indispensable element of human life and functioning. (Fig.3.) On the other hand, its inappropriate use may disfigure a given architecture, having a destructive effect on the image of a given place. (Fig.4.) The building of the Lublin Oncology Centre located in Lublin can be used as an example of improperly applied colour in architecture.

The body of the building with its colourful, loud orange-yellow façade dominates the view over a part of the city, and in a rather blatant way blends in with the panorama of the city. The nine-storey building located at Jaczewskiego Street is clearly visible from many parts of the city and this is due to the inappropriate use of bright and „,biting” colours on the façade. The location of the building on the elevation in an additional way exposes the nightmarish mass, exposing its imperfections. In the original plan, the façade was to be completely different, where instead of bright colours topped with a brown stripe, glass interlaced with light aluminium panels was to be used. Financial considerations forced investors to introduce changes to the façade, which would have been more economical but, as it turned out, destructive from a visual point of view. The use of bright, intense yellow and orange colours complemented by a dark shade of brown has contributed to the visual disfiguration not only of the building but of the entire area.

From a psychological point of view, it is well known that optimistic and vivid colours influence people in a positive way, adding energy and willingness to act. This is particularly important for the sick, as they often awaken in them the will to fight the disease, increasing their willingness to live. However, this type of argument does not justify the colour scheme used in the COZL. The therapeutic-therapeutic effect on the patient fulfils its purpose if it is used inside the room where the patient is staying. On the other hand, if colour is used on the external façade of the building, it loses its therapeutic effect and has a purely decorative or, as in this case, ,destructive” function. The bright yellow-orange colour scheme of the building is criticised by tourists, residents and architects, who call it „, nightmare”, ,gargamela” and „cancer”. The building also took second place in the „Macabryła 2015” competition for the biggest architectural fail of the year.

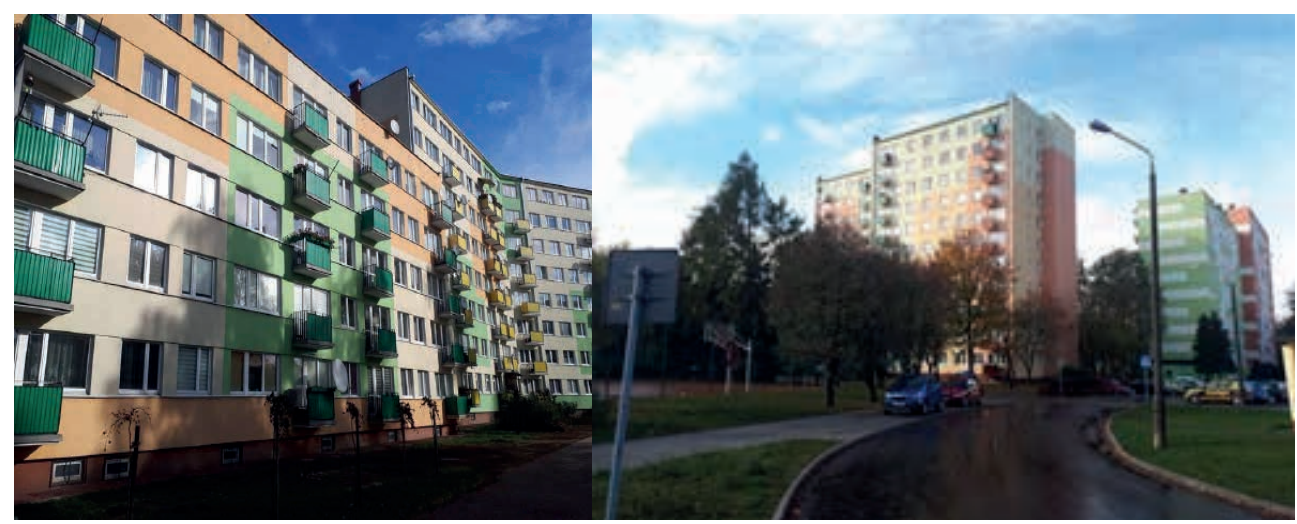

Fig. 1, 2. A residential block of flats on Smyczkowa street, 2018, author's photo. 


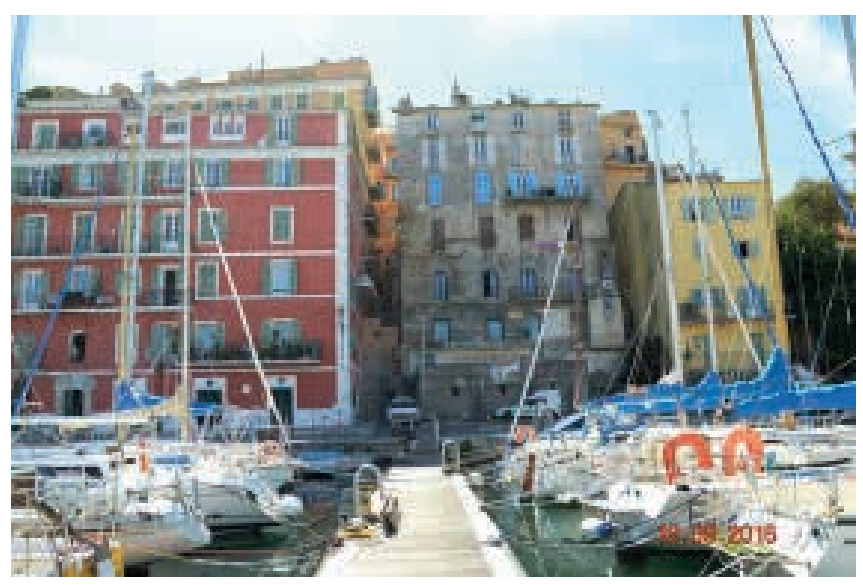

Fig. 3. Residential buildings renovated in colorful tones, Ajaccio, Corsica in France, 2016, author's photo.

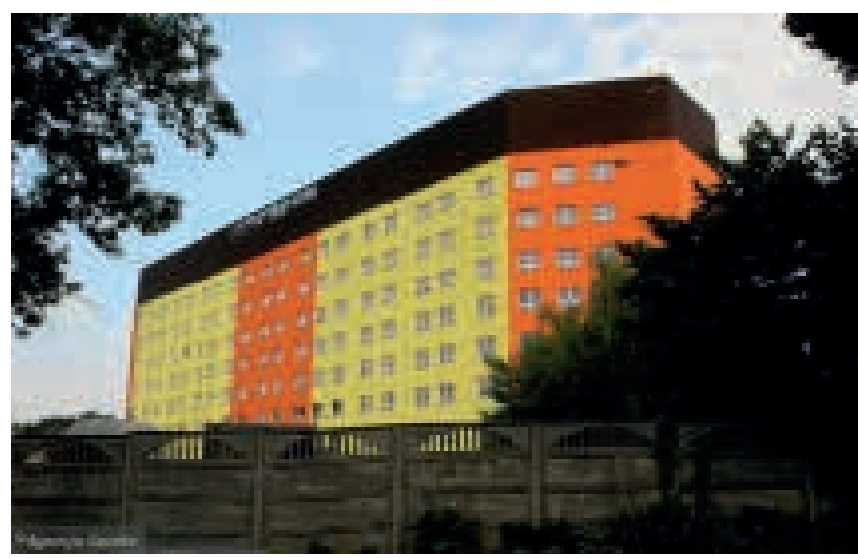

Fig. 4. Center of Oncology in Lublin, 2018, author's photo.

\section{The role of light in architecture}

Contemporary architecture finds many followers and continuators of the creative use of light. A good example is the Osaka Light Church (1989) of the Tadao Ando project, in which light naturally plays an independent role. The architect's concept of simplicity and legible geometry, with excellent precision, introduced sunlight in a controlled manner, which emphasized the individual elements and shapes of the architecture.

The Kimbell Art Museum in Forh Worth, designed by L. Kahn, is also an important example that perfectly emphasises the importance of light in architecture. The architect created a space of metaphysical significance, which was shown by means of light. The objective was achieved through the use of uniformity of materials, space, and appropriately introduced daylight [11].

Light has been explored and used in art, architecture and painting for centuries. Ancient Greeks are considered to be the precursors, who learned about phenomenon of light in depth. At that time this knowledge exerted a huge influence on the process of formation of numerous 
buildings, i.e. Roman Pantheon, Egyptian temples, Hagia Sophia or Greek cathedrals, recognizing light as a source of life [5].

One of the best examples of light from a fully enclosed interior illuminated from above is the Pantheon. Entering the interior, the greatest impression is made by the huge space, in which there is harmony and tranquillity. The whole structure is dark. As we reach the rotunda, we can see a gentle light coming in through a high hole in the ceiling, which is a metaphor for the connection between the buildings of the outside world and the heavenly vault. The evenly distributed light in the interior perfectly illuminates the beautiful marble floor, which reflects them to the sides and the rest of the room, giving softness and plasticity to the forms found there.

Hagia Sophia, the largest building in Istanbul, is another excellent example of the use of daylight in the „feeling” of the architectural interior. The palace church built by Emperor Justinian in 532-537 is the most perfect example of a dome basilica with a central layout. The three-nave building with 107 columns, covered with a dome, is filled with windows on all sides. The light entering through them provides amazing light effects that give the impression of a huge dome floating above the ground, becoming a lightweight, like an openwork vault. The rays of light falling into the interior give incredible plasticity and lightness, additionally illuminating beautiful interiors covered with mosaic patterns. A well-designed building, thanks to the appropriately introduced light, gives special attention to those elements that are most important in the church, giving them a majestic character.

Light in architecture is one of the tools that give an expressive form to a solid, without which space and its co-creating elements would have no raison d'être. It is not possible to control the intensity or colour of natural light, as it varies according to the time of day or year. Light allows us to look at architecture from a different perspective, it is a carrier of information, which not only allows us to look at it, but also to „,feel it”. More and more often the creation of space takes place thanks to the use of modern technological solutions, i.e. artificial lighting, which from a better perspective allows for the reception of a given object. Light, through its diversity, allows one to recognize the true plasticity of an architectural work and ,feel” it with all of oneself.

Light, which is a basic element necessary for the proper functioning of the human body, plays a very important role in the creation of architectural space. It makes it possible to present the building from a completely different perspective, creates new forms, emphasizing elements of architecture that deserve more attention of the audience. It allows to emphasize or blur borders, and weaken or enhance contrasts using the phenomenon of reflection and light penetration. Suggestive perception of space is possible thanks to the intensity of light and colour, which are used for creative presentation of a given interior and architectural objects contained therein. Modern technologies in the construction industry allow to combine the external and internal worlds, creating surprising visual effects. On the one hand, light can emphasise the shape of the building, and on the other hand, it creates the appearance of the perceived shapes, or partially masks them. Sufficient amount of daylight let into buildings allows the proper functioning of a person inside. Poorly lit buildings cause rapid fatigue, sluggishness, or depression due to the lack of sufficient daylight. That is why it is so important to skillfully introduce daylight already at the architectural design stage.

More or less concentrated light falling in the same direction best exposes form and texture, providing a sense of security and „,being” together in a given space [12]. It is one of the important factors shaping architecture, where, apart from plans, sections and elevations, 
it is an important element of usability for man. Architecture not only serves the purpose of admiring from outside, but also creates a space that satisfies the inner needs of man [12].

Many art theorists believe that light is one of the most important factors defining architecture. Modern engineers are often inspired by both natural and artificial light. More and more often used daylight, combined with innovative technology and various building materials, allows to design unique architectural objects that impress the viewer.

Contemporary architecture comprises of wonderful buildings, which surprise the viewers with unprecedented solutions both in terms of the selection of material and the use of light. The Scientific Information Centre and Academic Library in Katowice are good examples in which light naturally plays an important role. In the project, the authors used various materials such as concrete, steel, glass, brick or coloured mosaic in order to obtain interesting visual effects. The library building consists of two intersecting cubes with two glazed entrances. It is a compact monolithic mass covered with large sandstone slabs, which are separated by narrow windows. The stone covering the façade of the building was consciously selected by the architects because, ,its split texture and arrangement make the façade look different in the sun and different at dusk, different dry and different after rain, different in summer and winter, different from a close up and far away" [13]. The dense arrangement of the windows causes that after dark, they give the building the plasticity and mysteriousness, at the same time emphasizing its texture. The architecture is simple and legible in its geometry, dominated by concrete and steel. The intention was to use a large number of windows so that they would provide enough light for the reader's needs. The incoming light is controlled by the stream or reflection of the sun's rays. An important role is played here by the introduced aspect of „silence”, which is achieved by controlled introduction of light and the materials used. The design of the library, both inside and outside, uses simple and minimalist means of expression characteristic of contemporary architecture. The rhythmic layout of walls, bookshelves, and tables is complemented by wooden elements of balustrades and wooden floors, giving the interior a „warm” and cosy character. (Fig. 5,6,7)

An equally interesting public facility designed by Bolesław Stelmah is the Meeting of Cultures Centre in Lublin. Both inside and outside the building, we can observe the play of light scattered on various textures and structures. Glass, combined with raw concrete and steel elements, creates an unusual building, which is a marker of modern architecture. The building was designed with many glass surfaces so that sunlight could freely penetrate into the interior, to emphasize and exhibit the works of art presented there. The glass used, thanks to its excellent transparency, ensures greater permeability of daylight while illuminating the interior of the building. A glass exit to the roof and spatial glazed structures on the roof are an innovative approach to traditional building materials used in the project. The unique texture of glass on the façade of the building is characterized by a unique and uniform surface, which provides adequate illumination, creating an impression of privacy. The architect perfectly met the requirements set for him and designed a unique building, which perfectly fitted into the structure and character of the city. (Figures 8, 9, 10 and 11)

Bolesław Stelmach describes his building as connecting the past with the future. The sloping hills in front of the building symbolise the burial mounds associated with the past, while the glass multimedia facades reflect the present and the green roof is the near future of architecture [14]. 


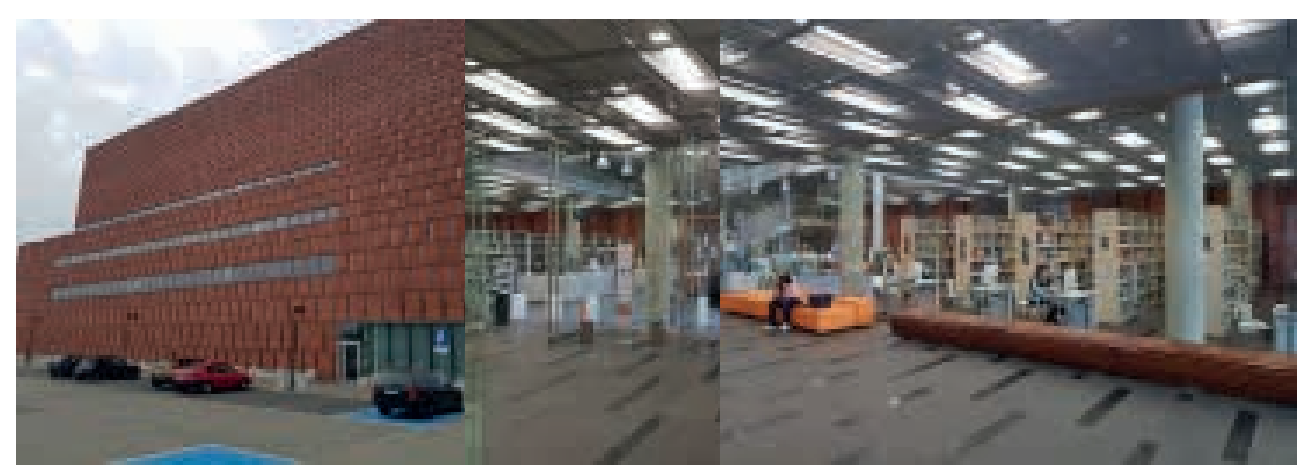

Fig. 5, 6, 7. Center of Scientific Information and Academic Library in Katowice, 2008, photog. Jacek Małyszek

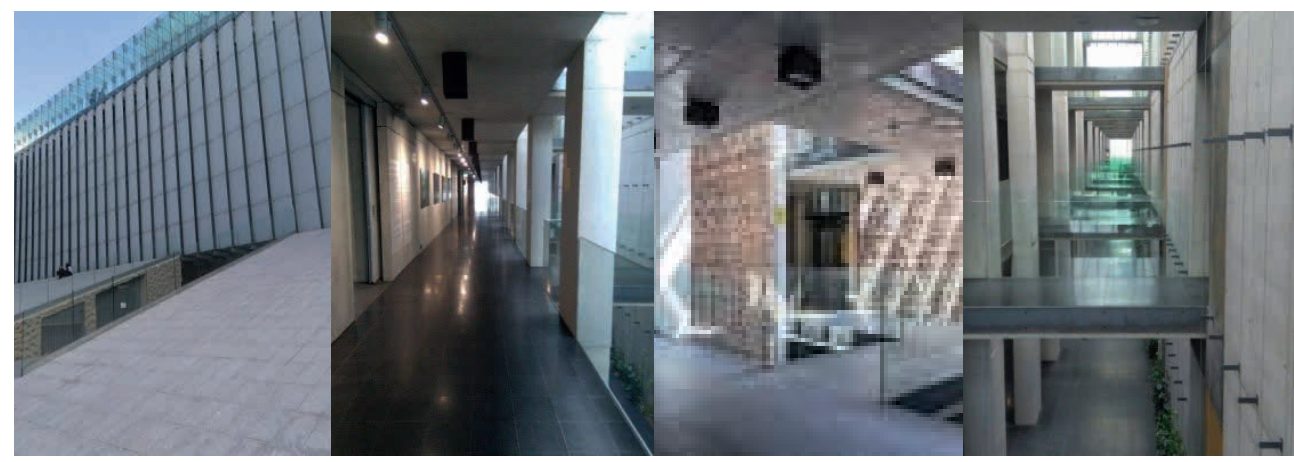

Ryc. 8, 9, 10, 11. The Cultures meeting center in Lublin, 2017, author's photo

Contemporary architectural trend, in search of originality, uses the influence of light combined with raw materials and modern technology. Light is used as a key element necessary to maintain communication with the outside world. Light and colour complement each other, making it possible to better understand and „feel” architecture as a composition of three-dimensional and spatial solids.

\section{Conclusions}

Architecture, light, and colour have cooperated and complemented each other for centuries. Both colour and light intensity play an important role in architecture, as they are an essential tool for the creative presentation of architecture. Modern technology makes it possible to connect the outside world with the interior of the building, where the use of appropriate building materials allows an even better and more effective presentation of the building body, creating a unique visual effect. Light and shadow, on the one hand, shape and expose the silhouette, and on the other hand, can hide what is not very attractive. Regardless of the epoch or style in which it was created, light has always given architecture its own value and ensured also economic benefits that are important already at the stage of sustainable design. Multilateral use of light is possible thanks to a greater awareness of designers and huge technological possibilities. Regardless of current trends or fashion, the use of light in architecture has a timeless dimension. It reveals the aesthetic aspects of the buildings, 
showing their shape, texture or colours. It is an excellent material that can be formed. Thanks to its properties, it enables designers to create magnificent architecture in which materiality ceases to matter when it is not visible to the naked eye.

The basic function of light in architecture is to expose the building, its details and co-creating elements. More and more frequently, it also plays an entertaining, decorative and aesthetic role in a given space. Adequate light intensity in relation to a specific surface determines the perception of a given solid in urban space. The resulting light phenomena deepen the effect of seeing architectural forms, which allow an in-depth and profound „feeling” of architecture.

The architecture of light is a ,magical” field, upholding the heritage of the whole essence of humanity. Design, classical architecture, interior design, and photography intersect there. Light makes architecture one of the most complex, and at the same time, important art forms among other design and artistic specialties.

The beauty of today's architecture is, on the one hand, to build simple cubic solids with the appropriate use of modern materials. On the other hand, it is the ,art” of selecting individual elements, colour and light of the designed buildings. Contemporary architecture is, above all, a large amount of glass, brick, concrete and steel, and it is the ,architecture of light", which gives lightness, transparency, and illusory character to the building. It is an excavation of beauty by emphasizing ceilings or facades and giving an individual architectural context to the solid.

\section{Literature}

[1] Martyniuk - Pęczak J., Światła miasta, Wydawnictwo MARINA, Wrocław 2014.

[2] Gage J., Kolor i kultura. Teoria i znaczenie koloru od antyku do abstrakcji, thum. J. Holzman, Kraków 2008.

[3] Rabiej J., Architektura: sztuka transfiguracji, Gliwice 2013.

[4] Marcinkowski R. [red.], Słownik Języka Polskiego, tom 3, Wydawnictwo Naukowe PWN, Warszawa 1981.

[5] Płochoccy E. i Z., Światło odwieczna zagadka, Wydawnictwa Normalizacyjne Alfa, Warszawa 1988.

[6] Krokiewicz A., Zarys filozofii Greckiej, Aletheia 1995.

[7] Verdenius W.J., Parmenidesa koncepcja światła, Przegląd Filozoficzny 2/54 (1992) 281.

[8] Nawrot A., Karolczak D., Jaworska J., Encyklopedia fizyki z astronomią, Wydawnictwo GREG, 2011.

[9] Konarski S., Światło i barwa, Instytut Wydawniczy Zawiązków Zawodowych, Warszawa 1982.

[10] Linton H., Color on Architecture. Design Methods for Buildings, Interiors and Urban Spaces, New York 1999.

[11] Ando T., Fehn S., Wolf G., Fehn T., Wolf S., Ando G., The Secret of the Shadow: Light and Shadow in Architecture, Wasmuth 2002.

[12] Rosmussen S. E., Odczuwanie architektury. Wydawca Karater, Kraków 2015.

[13] Wywiad dla tygodnika „Polityka” Piotr Śmierzewski z HS99. http://www.ciniba.edu.pl/ [dostęp: 17.07.2016].

[14] http://www.architektura.info/index.php/architektura/polska_i_swiat/centrum_spotkania_ kultur_w_lublinie [dostęp: 16.09.2016]. 


\title{
Światlo i kolor jako kluczowy element 'odczuwania architektury'
}

\author{
Agnieszka Chęć-Małyszek \\ Katedra Architektury, Urbanistyki i Planowania Przestrzennego, Wydzial Budownictwa \\ i Architektury, Politechnika Lubelska, e-mail: a.chec-malyszek@pollub.pl, ORCID: 0000-0001- \\ 6004-0635
}

Streszczenie: Niniejszy artykuł w szczególny sposób zwraca uwagę, na rolę jaką pełni światło w odbiorze współczesnej architektury. Światło stanowi zasadniczy element kreujący i uwidaczniający piękno architektury, podkreśla jej walory estetyczne i pozwala odczuwać nieograniczoną przestrzeń „,całym sobą”. Od zarania dziejów światło w połączeniu z kolorem odgrywało istotną rolę już na etapie projektomania a później jej odbioru. Współcześnie postęp technologiczny i cywilizacyjny przyczynił się do zwiększenia roli światła i koloru umożliwiając zastosowania ich już momentu projektowania. Wzrastające oczekiwania wobec architektów spowodowały intensyfikację zjawiska, która coraz częściej wyrażana jest realizacjami przepełnionymi światłem i kolorem.

Słowa kluczowe: architektura, światło w architekturze, odczuwanie architektury 